закладів позашкільної освіти дає змогу ефективно втілити ще одну ідею В. Сухомлинського, який зазначав, що колектив виконує дві основні функції у самовихованні школярів: створює загальні передумови й умови для самостійного та стійкого процесу самовиховання й організовує цей процес. Перша функція проявляється в тому, що колектив формує в учнів позитивне ставлення до соціально значимих видів діяльності, розвиває прагнення й бажання брати активну участь у колективній діяльності, стимулює самостійність, громадський обов'язок, ініціативність тощо. Друга функція проявляється в безпосередній організації самовиховання: у формуванні самосвідомості учнів, стимулюванні позитивної мотивації для роботи над собою, наданні допомоги під час планування й оцінки результатів своїх зусиль [6].

Таким чином, процес самопізнання дає змогу дитині на кожному з етапів іiі онтогенезу виробити певне ставлення до своїх позитивних рис характеру й індивідуальних можливостей (переваг), а також і до недоліків, тобто формувати самооцінку, яка є важливим регулятором власних вчинків, поведінки та діяльності. Саме від рівня самооцінки залежить комфортність та ефективність стосунків дитини з оточуючим іiї світом, критичність і самокритичність щодо результатів своєі діяльності в учнівсько-педагогічному колективі закладу позашкільної освіти, рівень вимогливості до себе, ставлення до своїх успіхів та невдач. У сукупності це створює умови підвищення ефективності процесів самовиховання зростаючої особистості.

Висновок. Динамізм, притаманний сучасному українському суспільству, зростання соціальної ролі особистості, гуманізація та демократизація суспільних відносин потребують розробки життєздатної системи забезпечення інтелектуального, духовного та фізичного самовдосконалення зростаючої особистості. Успіх виховання, а отже, і самовиховання, залежить від того, наскільки педагогічно доцільно учитель застосовує той чи інший метод або методичний прийом впливу на дитину, наскільки вони відповідають поставленим завданням і цілям її самовиховання.

Перспективи подалыших наукових досліджень вбачаємо в аналізі проблеми залучення дітей та учнівської молоді до конкретних соціально значущих виховних заходів, спрямованих на розв'язання (як індивідуально, так і в колективі) питань підвищення соціальної та творчої активності особистості, забезпечення умов її ефективного самовиховання в різних соціальних інститутах.

\section{СПИСОК ВИКОРИСТАНОЇ ЛІТЕРАТУРИ}

1. Основи теорії виховання : навч. посіб. / В. М. Синьов, О. І. Кривуша, М. О. Супрун ; за ред. В. М. Синьова. - К. : КІВС, 2000. - 140 с.

2. Сухомлинський В. О. Виховання і самовиховання / В. О. Сухомлинський // Вибрані твори : в 5 т. - К. : Рад. шк., 1977. - Т. 5. - С. 229-239.

3. Сухомлинський В. О. Методика виховання колективу / В. О. Сухомлинський // Вибрані твори : в 5 т. - К. : Рад. шк., 1976. - Т. 1. - С. 403-640.

4. Сухомлинський В. О. Павлиська середня школа / В. О. Сухомлинський // Вибр. тв. : в 5 т. -К. : Рад. шк., 1977. -Т. 4. - С. 7-392.

5. Сухомлинський В. О. Серце віддаю дітям / В. О. Сухомлинський // Вибр. тв. : в 5 т. - К. : Рад. шк., 1976. - Т. 3. - С. 7-282.

6. Сухомлинський В. О. Сто порад учителеві / В. О. Сухомлинський // Вибрані твори : у 5 т. - К. : Рад. шк., 1976.- Т. 2. - С. 419-654.

7. Сухомлинський В. О. Труд душі / В. О. Сухомлинський // Вибрані твори : в 5 т. - К. : Рад. шк., 1977. T. 5. - C. 600-605.

Дата надходження до редакиї: 06.08.2019 р.
УДК 37.091.4:37.013.74-047.44

DOI: 10.37026/2520-6427-2019-99-3-27-33
Алла ЧЕРНІЙ,

кандидатка політичних наук, дочентка, ректорка Рівненського ОІППО

В'ячеслав ДОЛІД, кандидат історичних наук, доцент, проректор із науково-педагогічної та навчальної роботи Рівненського ОІППО

\title{
В. СУХОМЛИНСЬКИЙ ТА Р. ШТАЙНЕР: ПОРІВНЯЛЬНИЙ АНАЛІЗ ПЕДАГОГІЧНИХ ІДЕЙ
}

У статті представлено загальний концептуальний нарис основних ідей і досвіду видатних педагогів В. Сухомлинського та Р. Штайнера, здійснено їх компаративний аналіз.

Ключові слова: В. Сухомлинський, Р. Штайнер, освіта, розвиток, виховання.
В статье представлен общий концеептуальный очерк основных идей и опыта выдающихся педагогов В. Сухомлинского и Р. Штайнера, осуществлен их компаративный анализ.

Ключевые слова: В. Сухомлинский, Р. Штайнер, образование, развитие, воспитание. 
Today in the conditions of reforming the national education system, studying the best pedagogical achievements of the past, research and analysis of the most important directions in the history of pedagogical thought will bring no less benefit for the development of the modern educational system than those or other innovations. Special interest are to comparative historical and pedagogical studies, in particular those devoted to the ideas of eminent teachers and educators of the past.

Celebrating the 101st anniversary of V. Sukhomlynsky birth, we again turn to the creative heritage of this prominent educator, who gives us the opportunity to understand the past of the education system and to create new practices based on its analysis, which will help to provide the necessary conditions for the development of education today.

$V$. Sukhomlynsky has made a profound contribution not only to the national but also to the world pedagogical science and practice. In less than 52 years of his life he has written and published 48 books, 500 scientific articles, more than 1500 stories and fairy tales for children. His works have been published in 53 languages of the world with a total circulation of more than 15 million copies. The works of the teacher are still being actively studied, and ideas are being put into practice in education and upbringing. V. Sukhomlynsky continued the best humanistic traditions in pedagogy of J. Komensky, L. Tolstoy, R. Steiner, and J. Korchak.

The article presents a general conceptual sketch of the main ideas and experiences of prominent teachers of V. Sukhomlynsky and $R$. Steiner and their comparative analysis.

Key words: V. Sukhomlynsky, R. Steiner, education, development, education.

Як відомо, велике бачиться на відстані. Саме ця неспростовна істина найдоречніше підходить для характеристики педагогічних ідей Василя Олександровича Сухомлинського. Відзначаючи 101-шу річницю від дня його народження, ми знову звертаємося до творчої спадщини видатного педагога, яка дає нам можливість зрозуміти минуле системи освіти і на основі його аналізу створити нові практики, які допоможуть забезпечити необхідні умови для розвитку освіти сьогодні.

Своєю винятковою обдарованістю і надзвичайною працьовитістю, великим оптимізмом і сміливим новаторством Василь Олександрович зробив неабиякий вклад не лише у вітчизняну, а й світову педагогічну науку і практику. Вдумаймося хоча б у такі цифри: за неповних 52 роки свого життя він написав і опублікував 48 книг, 500 наукових статей, більше як 1500 оповідань і казок для дітей. Масштаби вивчення й розповсюдження творчого доробку педагога-новатора вражають: його твори видані 53 мовами світу загальним тиражем понад 15 мільйонів примірників. Твори педагога і сьогодні активно вивчаються, а ідеївпроваджуються у практику навчання та виховання.

B. Сухомлинський продовжував найкращі гуманістичні традиції в педагогіці, які сягають своїм корінням Я. Коменського, Л. Толстого, Р. Штайнера, Я. Корчака.

Сьогодні, в умовах реформування вітчизняної системи освіти, вивчення кращих педагогічних досягнень минулого, дослідження й аналіз найважливіших напрямів в історії педагогічної думки принесуть не меншу користь для розвитку сучасної системи освіти, ніж ті чи інші нововведення. Особливий інтерес становлять порівняльні історико-педагогічні дослідження, зокрема ті з них, що присвячені ідеям видатних педагогів та діячів освіти минулого. Саме це й зумовлює мету пропонованої статті, яка полягає в проведенні компаративного аналізу педагогічних поглядів Василя Сухомлинського та Рудольфа Штайнера.

Дві постаті - Рудольф Штайнер і Василь Сухомлинський - відомі й знані творці оригінальних освітніх систем. Ідеї, погляди, що їх висловлювали обидва педагоги, значно випереджували свій час.

Професор університету Монаша (Австралія) Алан Кокеріл виокремлює шість спільних ознак у навчальних підходах, які практикували та пропагували В. Сухомлинський і Р. Штайнер. Охарактеризуймо їх:

1. Погляд на освіту як комплексну систему заходів, спрямованих не лише на розвиток інтелекту дитини, а й іiі моральних якостей та фізичних здібностей.

2. Погляд на вчителя як наставника у поєднанні 3 необхідністю колегіальної відповідальності усього педагогічного колективу за кожну дитину.

3. Необхідність докладного вивчення життя кожного учня з метою підтримки їхнього розвитку, підтримка тісного контакту з родинами дітей.

4. Визнання необхідності залучення дітей до освітнього процесу, особливо в початковій школі, на емоційному рівні, через казки, образні ігри, мистецьку творчість і фізичну діяльність. Навчання має надихатися почуттям подиву.

5. Доречність тісного взаємозв'язку з природою і значний акцент на естетичний розвиток.

6. Прив'язка ранньої грамотності до розвитку усного мовлення і малювання [6, с. 23-24].

Спробуємо проілюструвати кожну 3 наведених вище тез конкретними прикладами із творчості означених педагогів, які залишили багатий літературно-педагогічний спадок.

1. Уся педагогічна творчість В. Сухомлинського пронизана орієнтацією на цілісне виховання дитини. Своє призначення і виховний ідеал школи педагог вбачав у вихованні всебічно і гармонійно розвиненої особистості. Ця ідея отримала своє практичне застосування та розвиток у педагогічному досвіді Павлиської середньої школи. Із перших днів перебування дитини в школі важливо навчити ії мислити, орієнтуватися на життя в суспільстві, висловлювати свою думку. Василь Олександрович вважав, що мисленнєва діяльність як на уроках, так і поза ними має бути значно багатшою та ширшою, ніж усе те, що дитина робить на уроці. Чимало думок Сухомлинського, сказаних у минулому столітті, є надзвичайно актуальними й сьогодні. Згадаймо їх: «Навчання не повинно зводитися до безперервного нагромадження знань, до тренування пам'яті, до зубріння, яке отупляє, одурманює і нічого не дає, крім шкоди для здоров'я і розумового розвитку дитини. Я поставив собі за мету домогтися того, щоб навчання було частиною багатого духовного життя, яке сприяло б розвитку дитини, збагачувало іï розум. Не зубріння, а цікаве, різноманітне інтелектуальне життя, що проходитиме у світі казки, гри, краси, музики, фантазії, творчості таким буде навчання моїх вихованців. Хочеться, щоб діти були мандрівниками, відкривачами й творцями в цьому світі. Спостерігати, думати, розмірковувати, переживати радощі праці й пишатися створеним, творити красу й радість для людей і знаходити в цьому творенні щастя, захоплюватися красою природи, музики, мистецтва, збагачувати свій духовний світ цією 
красою, брати близько до серця й радість і горе інших людей, переживати їхні долі як глибоко особисту справу - такий мій ідеал виховання» [3, с. 101-102].

Видатний педагог часто брав своїх учнів на довгі прогулянки навколишньою місцевістю. Навчання проводилося в саду, гаю, на березі річки. На природі дитині необхідно надати можливість послухати, подивитися, відчути. На думку Василя Олександровича, саме $з$ пізнання природи починається становлення розуму, почуттів, поглядів, переконань. Ця думка грунтується на психофізіологічних властивостях дитини, природа мозку якої вимагає, аби іiі розум виховувався біля джерела думки - серед наочних образів i, насамперед, серед природи, щоб думка переключалася з наочного образу на «обробку» інформації про нього. Під час цих екскурсій у дітей розвивалися сила та витривалість, стимулювалися допитливість та мислення, формувалося усвідомлення природньої краси, а також відбувалася їхня соціалізація у процесі спілкування з членами місцевої громади, особливо з літніми людьми.

Для Сухомлинського ядром цілісного освітнього підходу була моральність, а ядром моральності - емпатія. «Справжню людину неможливо уявити без добрих почуттів. Виховання, по суті, починається із формування душевної чуйності - вміння відгукуватися серцем, думками, почуттями на все те, що відбувається в навколишньому світі. Душевна чуйність - це той загальний фон гармонійного розвитку, на якому будь-яка людська якість - розум, працьовитість, талант - набуває справжнього змісту, дістає найбільш яскраве звучання», - розмірковує педагог-новатор [4, с. 24].

Він вибудував систему морального виховання для школярів, в якій головними були етичні бесіди, які розкривали моральні цінності, норми, викликали моральні почуття - обов'язку, чуйності, поваги. Моральне виховання необхідно починати 3 дитинства, щоб у роки юнацтва вихованці на основі моральних цінностей здійснювали благородні вчинки, формували правильні погляди, позиції щодо мети і сенсу життя, своїх обов'язків.

Підхід до дитини як до єдиного цілого - головний педагогічний принцип Р. Штайнера. Він вбачав основне завдання виховання у концентрації в людині «вільного духу», під яким розуміється поєднання інтелектуальних і душевних можливостей, його реалізацію в життєвій практиці. Наслідки такої реалізації полягають у тому, що всебічно розвинені особистості стають запорукою та головною умовою культурного розвитку всього суспільства. Штайнер також вважав, що гарною людиною $є$ той, хто може співчувати іншим, адже від цього залежить справжня мораль, а без моралі неможливо підтримувати соціального порядку на землі [7].

2. Програми в усіх школах однакові, але школи різні, адже різні вчителі. Школа - це передусім учитель. Особистість учителя - наріжний камінь виховання. Усе, що відбувається в процесі виховної роботи, зокрема формування поглядів, переконань, ідеалів, світогляду, інтересів, захоплень, - усе, як у фокусі, зводиться до особистості педагога. У ньому переломлюються громадські, політичні, моральні, естетичні ідеї, істини, погляди. Все це, лише пройшовши крізь його особистий світ, відображається на вихованцеві, повторюється в ньому на вищому рівні. Найголовніше, на думку Сухомлинського, що відтворює вчитель у своїх вихованцях, це - ідеали. Вчитель, особливо в початковій школі, має бути не просто викладачем, а насамперед наставником і помічником. Видатний педагог згадував, що «в Павлиській школі я багато разів переконувався в тому, яку величезну роль у житті дитини відіграє вчитель початкових класів. Він повинен бути для дитини такою ж дорогою і рідною людиною, як мати. Віра маленького школяра в учителя, взаємна довіра між вихователем і вихованцем, ідеал людяності, який бачить дитина в своєму вихователеві, - елементарні й, разом із тим, найскладніші, наймудріші правила виховання, зрозумівши які, вчитель стає справжнім духовним наставником» [3, с. 15].

Подібну думку можна 3 легкістю віднайти й у Штайнера, який покладав величезні надії на вчителя, а також вважав, що школа повинна підтримувати особисте зростання своїх педагогів і допомагати їм у вирішенні будь-яких проблем.

Сухомлинський намагався не перевантажувати вчителів частими зустрічами, обмежував кількість педагогічних рад, надавав їм достатньо вільного часу для власного професійного зростання. На основі власного багаторічного досвіду Василь Олександрович рекомендував молодим директорам шкіл розвивати в колективі почуття колективної відповідальності та колегіальності: «Державне керівництво школою 3 боку директора ми прагнемо поєднувати 3 колегіальністю обговорення і розв'язанням важливих питань навчально-виховної роботи. Ефективність колегіальності залежить від спільності поглядів на принципові питання, що визначають напрям, суть виховання. Ця спільність педагогічних поглядів і переконань дає змогу нашим учителям розв'язувати колективно на засіданні педагогічної ради - практичні питання життя і роботи школи» [4, с. 65]. Стосовно того, як і завдяки чому створюється педагогічний колектив, у Сухомлинського була однозначна відповідь: його творять колективна думка, ідея, творчість. Відкритість кожного, взаємний обмін ідеями, живе педагогічне середовище, єдність духовного життя вихователя i вихованців - ось умова успішного розкриття потенціалу кожного учня і педагога.

Ідея повного шкільного самоврядування закладена й у вальдорфських школах, нерозривно пов'язаних з ім'ям їх засновника - Р. Штайнера. Вона реалізується передусім у процесі колегіального керівництва закладом, яке здійснюється на щотижневих конференціях, в яких на рівноправних засадах беруть участь усі вчителі. Конференція поділяється на педагогічну, адміністративно-організаційну та «внутрішню» частину. Під час педагогічної частини конференції проводиться самоконтроль і самоаналіз, осмислюється педагогічний досвід учителів. Адміністративна частина конференції стосується організаційних питань роботи школи. Під час «внутрішньої» частини обговорюються основні питання управління школою, прийому та звільнення співробітників [1, с. 122-123].

Директор для Сухомлинського - насамперед педагог, і педагог першокласний. Вважаючи, що має бути прикладом для вчителів та учнів, Василь Олександрович знав усі шкільні предмети, постійно цікавився науковими новинками і цим пробуджував пізнавальний інтерес в інших: «...виховання в широкому розумінні - це постійне духовне збагачення - оновлення як тих, хто виховується, так і тих, хто виховує... Керівник школи буде хорошим, авторитетним наставником учителів і учнів лише доти, поки він удосконалює свою майстерність і майстерність учителя й вихователя. Хороший директор - це добрий організатор, 
вихователь 1 дидакт не лише щодо дітей, яких він навчає на своїх уроках, а й щодо всіх вихованців школи та вчителів» [4, с. 31].

Сухомлинський узяв собі клас шестирічних дітей і продовжував бути їхнім наставником упродовж одинадцяти років, до закінчення ними середньої школи. Ця практика була співзвучна з ідеологією Штайнера, згідно з якою процес формування душі дитини передбачає, щоб один і той самий учитель упродовж восьми років навчання вів основні предмети в класі, так учитель ближче пізнає кожну дитину та їі особливості.

3. Сухомлинський визнавав унікальність кожної дитини, вірив, що не існує дітей обдарованих і необдарованих, талановитих і звичайних. Одночасно найважливішою якістю вчителя він вважав здатність входити у внутрішній світ кожної дитини, розпізнавати, виявляти, розкривати в кожному учневі його неповторний індивідуальний талант. Педагоги повинні бути майстерними стратегами в тонкій справі виховання, враховувати індивідуальність кожного учня, знати, чим він «дихає», розуміти, хто потребує схвалення, а кому потрібний осуд. Знати вікові закономірності розвитку емоцій, основні потреби кожного віку, умови розвитку кожного вихованця, привносити в життя і діяльність школярів творчі начала й емоційне збагачення освітнього процесу. I в сучасному вихованні актуальними залишаються слова Сухомлинського: «Ось перед вами сорок малят - iз першого погляду вони здадуться вам дуже схожими одне на одного навіть зовнішніми рисами, але вже на третій, четвертий, п'ятий день, після кількох зустрічей із дитячим колективом, після кількох походів у ліс, у поле ви переконаєтеся, що кожна дитина - це цілий світ, неповторний і своєрідний. Якщо цей світ відкриється перед вами, якщо в кожній дитині ви відчуєте іiі індивідуальність, якщо у ваше серце постукають радощі й прикрощі кожної дитини й відізвуться вашими думками, турботами, тривогами, - сміливо обирайте своєю професією благородну вчительську працю, ви знайдете в ній радість творчості, адже творчість у нашій праці (я ще зупинюся на цьому) - це насамперед пізнавання людини, подив перед багатогранністю й невичерпністю людського» [2, с. 422].

Для Василя Олександровича школа - це не лише директор, педагогічний колектив, учні, а ще й їхні батьки. Сухомлинський пропрацював в одній школі двадцять два роки і добре знав кожну родину. У той час, коли писалися його найбільш зрілі твори, він навчав дітей своїх колишніх учнів. Він часто бував у дітей удома і спілкувався з їхніми батьками. Повсякденні бесіди показали, що не всі вони готові виконувати батьківські обов'язки. 3 огляду на це було створено «батьківську школу». Першочерговим, на думку педагога-гуманіста, було те, щоб дати батькам елементарні знаття 3 педагогіки, аби ті брали безпосередню участь у виховному процесі, адже гармонійний, усебічний розвиток можливий лише за умови, коли школа і сім'я будуть діяти одностайно. Десять років дитина навчається в школі, а батьки вчаться у «батьківській школі». До роботи з батьками залучалися керівництво школи, педагоги, лікарі, а також більш досвідчені батьки.

А що ж у Штайнера? Батьки, віддаючи своїх дітей у вальдорфську школу, беруть на себе зобов'язання тісно співпрацювати 3 педагогічним колективом, що дозволяє подолати достатньо типову для звичайних шкіл ситуацію, коли школа і родина діють розрізнено в питаннях виховання дітей. Ця співпраця проявляється в частих зустрічах на класних і загальношкільних батьківських вечорах, у процесі обговорення та вирішення найрізноманітніших питань, причому не лише педагогічних (наприклад, зміни навчального плану), а й господарсько-економічних (нове будівництво, ремонт тощо). Для цього в школах існують так звані органи консультацій та ініціатив. Окрім того, практично всі вальдорфські школи пропонують батькам різноманітні курси з питань педагогіки, мистецтва, ремесел, відіграючи роль справжніх освітніх центрів [1, с. 123].

У вальдорфських школах одним зі шляхів для розуміння потреб окремих дітей $є$ презентація класним керівником індивідуальних результатів навчання дитини на засіданні колегії вчителів, після чого колегія спільними зусиллями поглиблює розуміння сутності зростаючої людини, а також вирішуе конкретне педагогічне питання, орієнтуючись не на приписи, що даються ззовні державними органами управління, а передусім на педагогічну ситуацію, пов'язану з потребами конкретних дітей [6, с. 26].

Аналогічна практика була прийнята на учительських семінарах, що проводилися двічі на місяць в школі Сухомлинського: «Двічі на місяць по понеділках у нас проводять засідання науково-педагогічної ради або психологічного семінару, присвячені саме дитині. Немає нічого потрібнішого, кориснішого і цікавішого, ніж розмова про дитину.

Першу частину педагогічного понеділка становить розповідь когось із вихователів (класного керівника, керівника гуртка, організатора сімейного вогнища культури, знань, працьовитості, творчої праці та ін.) про духовне життя свого колективу, взаємний обмін цінностями і багатствами, колективні прагнення, радощі, прикрощі, переживання. Потім вихователь спиняється на одному чи двох вихованцях, характеризує їх особистість, вчинки, поведінку, при чому все це будується на яскравих фактах. Про дитину висловлюють думки інші вчителі, які добре знають ії або помічають труднощі в підході до неї, у взаємовідносинах iз нею. Стає зрозумілим, чого ми ще не знаємо про дитину, що упустили або чого не помітили. Зрештою колектив визначає, що повинен зробити той учитель, який уже $\epsilon$ вихователем даної дитини, а також хто 3 учителів може і повинен стати ще одним іiї вихователем. Смисл усього цього в тому, щоб збагатити духовне життя дитини, виховати в неї морально цінні потреби, запити, інтереси, розкрити в ній усе добре, побачити ту золоту жилку, яка з часом - за умови належного шліфування та обробки - визначить достоїнство і багатство іїі особистості» [4, с. 56-57].

Таким чином, колектив школи брав на себе колективну відповідальність за добробут кожної дитини.

4. Штайнер вважав, що у початкові шкільні роки діти навчатимуться краще, якщо 3 ними займатися емоційно, на рівні серця. Сухомлинський також вважав емоційну взаємодію вирішальною впродовж перших років, хоча він пояснював це з позиції фізіології дитини. Для цього варто звернутися до його праці «Серце віддаю дітям»: «У період дитинства мислення розумові процеси мають якнайтісніше пов'язуватися із живими, яскравими наочними предметами навколишнього світу. Нехай дитина спочатку не замислюється над причинно-наслідковими зв'язками, нехай вона просто розглядає предмет, відкриває в ньому щось нове. Хлопчик побачив розлюченого бика в оповитій вечірніми сутінками купі дерев. 
Це не просто гра дитячої фантазії, а й художній, поетичний елемент мислення. Інша дитина бачить у цих самих деревах щось інше, своє - вона вкладає в образ індивідуальні риси сприймання, уяви, мислення. Кожна дитина не лише сприймає, а й малює, творить. Дитяче бачення світу - своєрідна художня творчість. Образ, сприйнятий і в той же час створений дитиною, несе в собі яскраве емоційне забарвлення. Діти переживають бурхливу радість, сприймаючи образи навколишнього світу і додаючи до них щось від фантазії. Емоційна насиченість сприйняття - духовний заряд дитячої творчості. Я глибоко переконаний, що без емоційного піднесення неможливий нормальний розвиток клітин дитячого мозку. 3 емоційністю пов'язані й фізіологічні процеси, що відбуваються в дитячому мозку: в моменти напруженості, піднесення, захоплення відбувається посилене живлення клітин кори півкуль. Клітини в ці періоди витрачають багато енергії, але водночас і багато одержують від організму. Спостерігаючи протягом багатьох років розумову працю учнів початкових класів, я переконався, що в періоди великого емоційного піднесення думка дитини стає особливо ясною, а запам'ятовування відбувається найінтенсивніше.

Ці спостереження по-новому висвітлили процес навчання дітей. Думка учня початкових класів невід'ємна від почуттів і переживань. Емоційна насиченість процесу навчання, особливо сприймання навколишнього світу, - це вимога, що висувається законами розвитку дитячого мислення» [3, с. 45-46].

Пізніше Сухомлинський розвинув свою ідею: «Спостереження за розумовою працею дітей усе більше переконували мене в тому, що емоційні імпульси (почуття радісної схвильованості, захоплення, подиву) ніби пробуджують клітини кори, які дрімали, активізують їх діяльність. Досвід показував, що розумове виховання маленьких дітей має здійснюватися через розвиток у них потреби в пізнанні, цікавості, допитливості» [3, с. 125].

Невід'ємною складовою дидактичної системи Сухомлинського була казка. У Павлиській середній школі вона тісно поєднувалася 3 красою навколишнього світу, природи. Завдяки їй дитина пізнавала світ не лише розумом, а й серцем, душею. Казкові образи збагачували духовне життя школярів, ставали засобом вираження їхніх почуттів, вчили мислити образами. Сухомлинський не лише сам вигадував казки, а й заохочував своїх учнів робити те ж саме: «Я тисячу разів переконувався, що, населяючи навколишній світ фантастичними образами, творячи ці образи, діти відкривають не тільки красу, а й істину. Без казки, без гри уявлення дитина не може жити, без казки навколишній світ перетворюється для неї на гарну, але все ж намальовану на полотні картину; казка примушує цю картину ожити» [3, с. 33].

Педагог вважав казки абсолютно необхідними для морального розвитку дитини. Розуміючи й усвідомлюючи ідею лише тоді, коли вона втілювалася в яскравих образах, учні черпали в казці перші уявлення про справедливість і несправедливість, навчалися висловлювати своє відношення до добра і зла: «Якби в дітей не було всього цього, якби вони не переживали боротьби добра і зла, не відчували, що в казці відтворені уявлення людини про правду, честь, красу, їхній світ був би тісним і незатишним» [3, с. 70$]$.

Неабияким внеском Сухомлинського $є$ розробка теоретичного і методичного підгрунтя трудового виховання. У праці вчений-практик вбачав не лише велику виховну силу, а й вирішальну умову розвитку інтелекту: «Крім подорожей у природу та ігор, широкий простір для розвитку розумових і фізичних сил відкривається у фізичній праці. Не можна уявити повноцінного щасливого дитинства без того, щоб трудова діяльність не одухотворялася радісними, хвилюючими почуттями. Досвід переконує, що фізична праця для маленької дитини - це не лише набуття відповідних умінь і навичок, не тільки моральне виховання, а й безмежний, надзвичайно багатий світ думок. Цей світ пробуджує моральні, інтелектуальні, естетичні почуття, без яких неможливе пізнання життя, а отже, - й навчання» [3, с. 125].

5. Розвиток - одна 3 наскрізних ліній, що проходить через усі праці Сухомлинського. Це - відчуття краси i багатства природи, використання природи для підтримки багатьох аспектів освітнього процесу, включаючи інтелектуальний та естетичний розвиток: «Природа мозку дитини потребує, щоб ії розум виховувався біля джерела думки - серед наочних образів i насамперед серед природи, щоб думка переключалася 3 наочного образу на «обробку» інформації про цей образ. Якщо ж ізолювати дітей від природи, якщо $з$ перших днів навчання дитина сприймає тільки слово, то клітини мозку швидко стомлюються і не можуть впоратися з робою, яку пропонує вчитель. А цим клітинам необхідно розвиватися, міцніти, набиратися сил. Ось де причина того явища, з яким багато вчителів часто стикаються в початкових класах: дитина тихо сидить, дивиться тобі в очі, немовби уважно слухає, але не розуміє жодного слова, тому, що педагог розповідає і розповідає, тому, що треба думати над правилами, розв'язувати задачі, приклади - все це абстракції, узагальнення, немає живих образів, мозок стомлюється... А як наслідок - з'являється відставання. Ось чому треба розвивати мислення дітей, зміцнювати розумові сили дитини серед природи - це вимога природних закономірностей розвитку дитячого організму. Ось чому кожна подорож у природу $є$ уроком мислення, уроком розвитку розуму» [3, с. 34].

Вихователь має допомогти дитині побачити естетичне забарвлення світу навколо себе, лише ці образи залишаться 3 ним на все життя. Екскурсії у природу під наглядом учителя допомагають пробудити почуття подиву та зацікавленості, а також захоплення красою. Саме в природних умовах Сухомлинський знайомив дітей $з$ малюванням, музикою, структурою оповідань і поезії. Саме на природі діти навчалися читати і писати. Охоплюючи естетичними переживаннями природу, мистецтво, працю, людські відносини, вчинки, людина, на його думку, освоює світ і формує себе. Естетичному розвитку він присвятив важливі, пронизливі рядки свого літературного спадку: «В естетичному вихованні взагалі і в музичному особливо важливі психологічні настанови, якими вихователь керується, залучаючи дітей до світу прекрасного. Для мене головною була настанова на виховання здатності емоційно ставитися до краси і потреби у враженнях естетичного характеру. Важливу мету всієї системи виховання я бачив у тому, щоб школа навчила людину жити в світі прекрасного, щоб людина не могла жити без краси, щоб краса світу творила красу в ній самій» [3, с. 63].

Сухомлинський вважав, що зв'язок зі світом природи має неабияке значення для дитинства: «...забуває наша педагогіка, що учень добру половину 
всіх років навчання в школі залишається насамперед дитиною. Втовкмачуючи в дитячі голови готові істини, узагальнення, висновки, вчитель часом не дає їм можливості навіть наблизитися до джерела думки й живого слова, зв'язує крила мрії, фантазії, творчості. Із живої, активної, діяльної істоти дитина іноді перетворюється ніби в запам'ятовуючий пристрій... Нi, так не повинно бути. Не можна відгороджувати дітей від навколишнього світу кам'яною стіною. Не можна позбавляти учня радощів духовного життя. Духовне життя дитини повноцінне лише тоді, коли вона живе в світі гри, казки, музики, фантазії, творчості. Без цього вона - засушена квітка» [3, с. 67-68].

Поряд із чисельними екскурсіями у природу під час шкільних занять, Сухомлинський наприкінці кожного навчального року організовував літні табори під відкритим небом. До того часу, коли його учні закінчили початкову школу, всі вони мали чудове здоров’я і показували значні успіхи у навчанні.

6. Сухомлинський тісно пов'язував ранне навчання грамотності з розвитком усного мовлення і малюванням. Тема емоційної взаємодії також проходить через усі його твори про навчання грамотності: «Я домагався, щоб слово було для дитини не лише позначенням речі, предмета, явища, а й несло в собі емоційне забарвлення - свій аромат, найтонші відтінки. Важливо, щоб діти прислухалися до слова як до чудової мелодії, щоб краса слова і краса тієї часточки світу, яку це слово відображає, пробуджувала інтерес до тих малюнків, які передають музику звуків людської мови - до літер. Поки дитина не відчула аромату слова, не побачила його найтонших відтінків, - не можна починати навчання грамоти, і якщо вчитель робить це, то він прирікає дитя на тяжку працю (дитина зрештою подолає ці труднощі, але якою ціною!)» [3, с. 79].

Письмо зрощувалося малюванням, а малювання було частиною духовного життя дитини. Наступний уривок також ілюструє, як інтуїтивна реакція Сухомлинського на дітей переважає будь-яке формальне виховання, загальновизнане у педагогіці: «Я багато читав про методику уроків малювання, а тепер переді мною були живі діти. Я побачив, що дитячий малюнок, процес малювання - це частинка духовного життя дитини. Діти не просто переносять на папір щось із навколишнього світу, а живуть у цьому світі, входять у нього як творці краси, дістають насолоду від неї. Ось Ваня, весь захоплений своєю роботою, малює вулик, поряд дерево, на якому величезні квіти, над квіткою бджола, майже така завбільшки, як і вулик. У хлопчика розчервонілись щічки, в очах вогник натхнення, який приносить велику радість учителеві» [3, с. 53-54].

Ця думка співзвучна 3 міркуваннями Штайнеpa, які ми знаходимо у його публічному лекційному циклі, так званому «Базельському курсі». Він писав: «Мене зачепило за живе, коли в сучасній педагогічній літературі я зіткнувся 3 думкою, ніби навчання граматиці шкодить навчанню малювання, ніби вона - і мова загалом - штовхає людину до абстрагування. Вважають, що діти розучуються бачити, розучуються спостерігати те, що живе у світі як форми і фарби.
Цього, насправді, не буває, якщо мова дається не абстрактно, а виводиться із внутрішнього переживання. Тоді обидва предмети взаємодоповнюють один одного, і у віці близько дев'яти років можна спостерігати плоди самосвідомості завдяки тому, що вони поступово пронизують художнім почуттям переживання зовнішніх форм» $[5$, с. 76$]$. Викладання рідної мови також спрямовується насамперед на розуміння характерного у звуці, римі та ритмі, а також на форму i значення літер. Виведенням форми літери із малюнку, пов'язаного з характером звуку, дитина зможе розвинути індивідуальне ставлення до окремої літери, а потім і до всього процесу письма.

Підсумовуючи, зауважимо: по-перше, Рудольф Штайнер і Василь Сухомлинський жили в реаліях різних історичних епох і країн. Оскільки у жодному зі своїх творів Сухомлинський не згадував Штайнера, невідомо, чи ознайомлений він був 3 ідеями свого австрійського колеги. Однак беззаперечним лишається той факт, що філософія діяльності школи Сухомлинського багато в чому перегукується із вальдорфською педагогікою; по-друге, обидві концепції були настільки вдало педагогічно інструментовані всіма, здавалося б, давно відомими засобами навчання, що технологія їх засвоєння та практика застосування не викличе значних перепон у творчо працюючих педагогів.

\section{СПИСОК ВИКОРИСТАНОЇ ЛІТЕРАТУРИ}

1. Помелов Б. М. Рудольф Штейнер и его вальдорфская педагогика (к 150-летию со дня рождения) / Б. М. Помелов // Вестник Вятского государственного гуманитарного университета. - 2010. № 2. - C. 120-127.

2. Сухомлинський В. О. Вибрані твори : в 5 т. T. 2. Формування комуністичних переконань молодого покоління. Як виховати справжню людину. Сто порад учителеві / В.О. Сухомлинський. - К. : Рад. школа, 1976. - 670 с.

3. Сухомлинський В. О. Вибрані твори : в 5 т. T. 3. Серце віддаю дітям. Народження громадянина. Листи до сина / В. О. Сухомлинський. - К. : Рад. школа, 1977. -670 с.

4. Сухомлинський В. О. Вибрані твори : в 5 т. T. 4. Павлиська середня школа. Розмова 3 молодим директором школи / В. О. Сухомлинський. - К. : Рад. школа, 1977. - 640 с

5. Штайнер Р. Духовное обновление педагогики / Р. Штайнер ; [пер. с нем.]. - М. : Парсифаль, 1995. $251 \mathrm{c}$.

6. Cockerill A. Sukhomlinsky and Steiner: A Comparison / A. Cockerill // RoSE: Research on Steiner Education. - 2016. - Vol. 7. - № 1. - P. 22-30.

7. Steiner R. Truth Beauty and Goodness. A lecture by Rudolf Steiner Dornach, January 19, 1923. [Electronic resource]. URL: https://wn.rsarchive.org/Lectures/19230119p01.html (дата звернення: 20.07.2019).

Дата надходження до редакиії: 07.08.2019 p. 